"IFRS compliance and stock prices influence: evidence from Jordanian banks"

\begin{tabular}{|c|c|}
\hline AUTHORS & $\begin{array}{l}\text { Adel K. Almasarwah (D https://orcid.org/0000-0003-0928-2086 } \\
\text { Ahmad M. Omoush (D https://orcid.org/0000-0003-1601-6798 } \\
\text { Nizar Alsharari }\end{array}$ \\
\hline ARTICLE INFO & $\begin{array}{l}\text { Adel K. Almasarwah, Ahmad M. Omoush and Nizar Alsharari (2018). IFRS } \\
\text { compliance and stock prices influence: evidence from Jordanian banks. Banks } \\
\text { and Bank Systems, 13(3), 24-35. doi:10.21511/bbs.13(3).2018.03 }\end{array}$ \\
\hline DOI & http://dx.doi.org/10.21511/bbs.13(3).2018.03 \\
\hline RELEASED ON & Monday, 23 July 2018 \\
\hline RECEIVED ON & Friday, 16 March 2018 \\
\hline ACCEPTED ON & Friday, 06 July 2018 \\
\hline LICENSE & $\begin{array}{l}(c) \text { EY-NC } \\
\text { This work is licensed under a Creative Commons Attribution-NonCommercial } 4.0 \\
\text { International License }\end{array}$ \\
\hline JOURNAL & "Banks and Bank Systems" \\
\hline ISSN PRINT & $1816-7403$ \\
\hline ISSN ONLINE & $1991-7074$ \\
\hline PUBLISHER & LLC "Consulting Publishing Company "Business Perspectives" \\
\hline FOUNDER & LLC "Consulting Publishing Company "Business Perspectives" \\
\hline
\end{tabular}

NUMBER OF REFERENCES

43

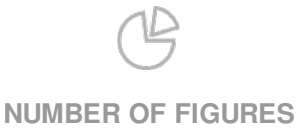

0

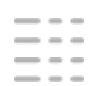

NUMBER OF TABLES

6

(C) The author(s) 2022. This publication is an open access article. 


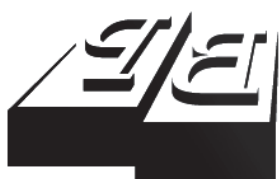

BUSINESS PERSPECTIVES

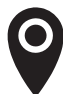

LLC "CPC "Business Perspectives" Hryhorii Skovoroda lane, 10, Sumy, 40022, Ukraine

www.businessperspectives.org

Received on: $16^{\text {th }}$ of March, 2018 Accepted on: $6^{\text {th }}$ of July, 2018

(C) Adel K. Almasarwah, Ahmad M. Omoush, Nizar Alsharari, 2018

Adel K. Almasarwah, Accounting Department, Business School, Hashemite University, Jordan

Ahmad M. Omoush, Accounting Department, Business School Hashemite University, Jordan

Nizar Alsharari, Accounting Department, Business School, United Arab Emiraties University, United Arab Emirates
Adel K. Almasarwah (Jordan), Ahmad M. Omoush (Jordan),

Nizar Alsharari (United Arab Emirates)

\section{IFRS COMPLIANCE AND STOCK PRICES INFLUENCE: EVIDENCE FROM JORDANIAN BANKS}

\begin{abstract}
This study aims to examine the IFRS compliance in Jordanian banks and its relation to stock prices. The impact of compliance with International Financial Reporting Standards (IFRS) on stock prices in Jordanian banks is a rarely researched subject in accounting and finance, but whether IFRS compliance has a serious impact on stock prices, particularly in developing countries, is still unknown. Numerous factors in developing countries, such as cultural, political, and economic circumstances, can create different effects for IFRS compliance from those seen in developed countries.

This paper concludes that IFRS compliance negatively affects stock prices, and firm size has a positive relationship with stock prices in Jordanian banks. The paper has significant implications for IFRS compliance research on stock prices, particularly across Jordanian banks, in responding to recent calls to bridge the gap that has been identified as a result of the revolutions in the Middle East. This study has been carried out in order to attract investors to avoid opposite results compared with prior literature that has studied the same subject. Hence, there are essential implications for the way in which successful IFRS compliance can be positively associated with stock prices in Jordanian banks.
\end{abstract}

\section{Keywords}

JEL Classification
IFRS compliance, stock price, return on assets, leverage ratio, Jordanian banks

\section{INTRODUCTION}

The adoption of International Financial Reporting Standards (IFRS) around the world has different international benefits. On the one hand, it can be considered an economic decision in relation to trade facilitation, since the adoption of IFRS leads to several financial benefits, such as enhanced transparency, greater earnings quality, facilitated trade, and comparability of financial data across firms' sectors (Chua \& Taylor, 2008). Recently, a large number of firms started preparing their financial reporting according to mandatory IFRS, leading to a new phenomenon of unified financial reporting. Therefore, most researchers have recently investigated the impact of this change (the adoption of mandatory IFRS) on diverse issues in the accounting (Christensen et al., 2013; Yurt \& Ergun, 2015). Few researchers as in this study explore the impact of IFRS compliance on stock prices influence in the banking sector.

Recent research indicates that cash from operating activities and discretional accruals are good indicators of Jordanian banks' market values. Book value and net income are good indicators of industrial firms' market values. IFRS adoption is more likely to lead to several features for financial reporting, such as increased quality of financial statements, increased financial report transparency, more easily com- 
parable information, and creation of in-depth information that will make appropriate decisions easier for the investors and other financial statement users, which will affect stock prices as one element of financial statements (Turki et al., 2017).

To investigate the association between IFRS compliance and stock prices in Jordanian banks, the authors performed several experimental analyses. Firstly, they assessed the relationship between IFRS compliance and changing stock price levels during the period of study. The authors find that IFRS compliance significantly influences stock price levels, which initially suggested that a high level of IFRS compliance would correlate with a high stock price. Secondly, however, the authors investigated if the high stock price levels usually related to the high levels of IFRS compliance. Surprisingly, this research documented the opposite results of its suggestion, and a negative relationship was instead found.

This research contributes to the prior studies on stock prices and IFRS compliance by providing indications as to the impact of IFRS compliance on stock prices using Jordanian bank data. This research analysis offers information specific to Jordanian banks, and examines the potential impact of this unique context. This study has significant inferences for decision-makers and financial statement users - whether internal or external - particularly those who assess and interpret the influence of IFRS compliance on stock prices, particularly in emerging markets, such as Jordan.

\section{LITERATURE REVIEW AND HYPOTHESES DEVELOPMENT}

\subsection{IFRS compliance development}

Recently, IFRS compliance has become the current debate for many researchers. It has received considerable attention from researchers exploring its impact on several aspects of business. A full disclosure of International Financial Reporting Standards (IFRS) brought a huge motivation for financial statement users, whether they are external or internal. Therefore, the users can apply the disclosure information to make proper decisions in order to achieve their desired objectives (Mazzi et al., 2017).

In a recent study in the UK, Ali et al. (2016) document that there are several motivations related to IFRS compliance, such as firm size (e.g., diffusing ownership concentration), operations size (e.g., increasing operations), financing rules (e.g., giving more flexibility to apply more policies in the firms) and increasing foreign capital investments (e.g., providing investors with more accurate and proper information to inform decisions). When this information is not provided, misrepresentation becomes more likely, since each user will use different resources to analyse the available financial information.
IFRS compliance has supporters and opponents in the literature, based on the diverse convictions of the researchers. Supporters of IFRS compliance document several benefits, including: (1) providn ing more accurate financial information, (2) saving time during the preparation of financial statements, (3) unifying all financial statements by reducing the differences between local accounting standards, and (4) higher accounting quality compared with local accounting standards (Barth, Landsman, \& Lang, 2008; Capkun et al., 2016; Loureiro \& Taboada, 2011). In contrast, opponents state that IFRS has several disadvantages which establish obstacles for countries adopting IFRS, whether voluntarily or compulsorily, such as decreasing financial statement quality (since each country has different established employee roles for preparation of their financial reports), limiting the employee roles that determine financial report quality, and affecting IFRS outcomes and implementations by forcing countries into unified accounting standards (Ball, 2006; Loureiro \& Taboada, 2011).

\subsection{Stock prices influence}

Stock price can be defined as the cost of purchasing the financial instrument from an exchange market, which some studies also call share price. Stock price is changeable from one period to another based on market forces results, such as demand and supply. 
Moreover, stock price is influenced by different factors, including firms' financial health, firm information, economic circumstances, and world- and nation-wide news (Byun \& Rozeff, 2003).

Generally, stocks can be divided into two types: (1) common stocks (ordinary shares) and (2) preferred stocks (preference shares), in the prior literature. Stock is widely considered one of the most important investment tools. Investors have, in previous studies, offered several reasons for increasing their investments, such as buying stock with low prices, particularly in new firms, in order to achieve long-term investment growth or expecting long-term stock growth stability from well-established firm stockholders (Masum, 2014).

The literature has documented that the financial users, whether internal or external (e.g., investors, government, and suppliers), based their decisions on the disclosed financial information (Foster, 1973). Therefore, stock price is not independent from the financial information published in annual financial reports. Sletten (2012) stated that the financial information hiding - or bad news publication - is likely to lead to decreased stock price. Sletten (2012) found a negative relationship between the disclosure of bad news and stock price variations; that is, higher instances of bad news lead to lower prices. Study findings to date have revealed, though, that an association does not necessarily exist between the publications of good news and increased stock prices for a firm. Furthermore, some studies document that financial users, such as investors, react more clearly to bad news than good news, since good news is published early and consequently is not a surprise to investors (Kothari, Shu, \& Wysocki, 2009).

A perception that a firm is withholding bad or good news that is directly related to a firm's financial statements likely has a direct impact on stock price. For example, Tucker and Zarowin (2006) and Skinner (1997) introduced significant empirical evidences that the early disclosure, by managers, of bad news that might affect stock prices leads to reduced litigation costs. Dye (1985) used a different model than prior studies and pointed out that the full disclosure of financial information leads to higher stock prices. His conclusion was that a solid base of reliable, extant financial information increases trust in the firms and in firms' financial reports. In another context of Egypt, Ansary and El-Azab (2017) assume that the announcement of a stock split is likely to lead to preferred stock prices, because this decision is seen as improving firm profitability and liquidity.

\subsection{IFRS compliance and stock price influence}

The literature has argued that stock issues may offer incentives for managers to manipulate firm earnings in order to achieve certain, desirable goals. Therefore, the accounting regulators established, first, the international accounting standards (IAS), then IFRS, to reduce the potential for embezzlement and manipulation in financial statements, where the stock price offers one statement of financial position (Rudra \& Bhattacharjee, 2012). Furthermore, three theories have been introduced in the literature to address stock issue manipulation. Agency theory is focused on separating between managers (agency) and ownership (principal) responsibilities. Efficient contracting theory is focused on using managers to develop accounting discretion, particularly for long-term solutions. Opportunist theory states that the managers' incentives for manipulating firm earnings should be reduced by using particular financial tools, particularly in the short term.

Ball (2006) stated that the IFRS was established as a new system to integrate all the financial systems in the world under one system for different purposes. For example, providing accurate, timely and comprehensive financial statement information; allowing small investors to easily understand financial statements; reducing the difference between firms' financial statements by creating an integrated system; and mitigating the cost and time required to obtain information. On the other hand, Ball clarifies that there are some obstacles that might face IFRS, such as a shortage of qualified people during the system transition. The weaknesses in IFRS compliance could lead to negative effects on firms' financial statements, increasing earnings at the management level and decreasing firm performance. In other words, earnings at the management level are negatively related to IFRS compliance. Stock price is considered a motivation for opportunistic earnings management (Rezaei, 
2012). In this regard, Elbannan (2011) found that the mandatory adoption of IAS in Egypt during the period of 1997 to 2006 positively affected the overall stock market, using Tobin's $\mathrm{Q}$ to evaluate firm performance. On the other hand, he documented that IAS adoption negatively related to stock value in other firms in the same period.

Capkun et al. (2016) documented that the early adoption of IFRS has several incentives for EU firms, such as increased financial statement quality and transparency that can attract outside capital. In the context of Africa, Nnadi and Soobaroyen (2015) found an opposite result compared with prior studies, where they revealed that there is a negative relationship between IFRS compliance and foreign direct investment in more than thirty Africa developing countries. They connected this result to several factors that the African countries studied faced through their research: first, increases in cost of operation in the IFRS-regulated environment; second, changes to the law and legal systems; and, third, corruption.

In prior studies, several researchers have examined the impact of IFRS compliance on different fields, such as the relationships between IFRS and accounting information. Alali and Foote (2012) examine the impact of IFRS on accounting information in Abu Dubai Stock Market, where they found that the adoption of IFRS leads to increases in price per share, earnings per share, and book values per share. Regarding IFRS and auditor choice, Hodgdon et al. (2009) stated that the auditor choice should be positively related to high levels of IFRS compliance, since a higher IFRS compliance enhances the quality of the produced financial statements. Their findings supported their main hypothesis, which is that a higher IFRS compliance level relates positively with audit choices.

Based on a sample of 3,994 firms in thirty countries, Loureiro and Taboada (2011) studied the impact of mandatory and voluntary IFRS adoption on stock prices. Their findings were as follows: increased stock prices are strongly related to IFRS adoption, particularly when the managers have incentives to improve their financial reporting quality, and increased stock prices are positively related to voluntary IFRS adoption, particularly in countries that have stronger public enforcement.
In the context of Canada, Anderson et al. (2016) found that compliance with IFRS correlated to higher stock prices and firm values compared with compliance with GAAP. In the context of emerging countries (e.g., Greece), Maggina and Black (2016) found that ignoring some factors, such as political and macroeconomic ones, negatively affected the relationship between IFRS compliance and earnings, shareholder's equity, and financial ratios. Accordingly, they inserted consideration of these factors to explore the association between IFRS compliance and financial statement data, such as earnings stock prices and some financial ratios. Their findings showed that the IFRS compliance positively related to financial ratio improvement; on the other hand, no relationship was found with stock price.

Based on a sample of 21,608 firm-years across 34 countries during the period of 1998 to 2004, Kim et al. (2014) studied the impact of voluntary IFRS on cost equity, where they found that the firms that have adopted IFRS supported their main hypothesis: 'the full adoption of IFRS is more likely related to lower cost equity', compared with firms that have not adopted IFRS. In the same vein, Li (2010) presented significant empirical evidence that IFRS compliance is likely to lead to reduced capital costs and improved market liquidity. In contrast, though, Christensen et al. (2013) found little impact of IFRS compliance on firm liquidity in all countries included in their study, and they documented that the liquidity benefits occurred regardless of the weakness of the relationship between IFRS compliance and firm liquidity.

Based on the discussion offered in the prior literature, this research used the two hypotheses below to investigate the nature of the relationship between IFRS compliance and stock prices in Jordanian banks and to explore some factors that might affect this relationship.

H1: The stock price is higher for the banks that have higher levels of IFRS compliance, compared with those who do not comply.

H2: The effects of IFRS compliance on stock price differ between banks with higher IFRS compliance and firms with lower compliance. 
This paper contributes to existing literature in several ways. The literature review discloses that most studies investigating the relationship between IFRS compliance and stock prices in Jordanian banks tend to restrict measures to compulsory or voluntary of IFRS compliance and relate them to stock prices. This research paper studies a similar area in a much wider context and involves a greater range of research techniques, which has included compulsory and voluntary IFRS adoption. In the context of stock prices, researchers have previously used several techniques for measurement purposes, such as stock return, stock price synchronicity, and average stock price (high and low). This paper has used stock return. In addition, the economic conditions in Jordan since 2008 (i.e. the financial crisis and the revolutions in the Middle East) have been problematic for Jordanian banking firms, which may have led to some problems that could affect stock price and IFRS. Accordingly, several factors have been presented in this research analysis, including a number of factors specific to the context of Jordan, which have not been identified by other studies, such as cultural factors and revolutions in the Middle East.

\subsection{Study objectives and motivations}

This research aims to study the processes of stock prices in Jordanian banks and their relationship with IFRS adoption. In order to do this, the authors set out a few objectives as follows: to explain the nature of the relationship between stock price and IFRS adoption in Jordanian banks; to identify the characteristics of IFRS adoption that are most influential on stock price; to analyse the motivations that could potentially lead Jordanian banks to improve and develop their systems in order to achieve the IFRS requirements; to assess the econometric power and appropriateness of study model in providing more accurate results that exist between stock price and IFRS in the context of Jordanian banks.

The importance of this study has come from several motivations. Jordan is one of the growing countries that require attracting new investors, lenders and other members in business. The publication of stock price and IFRS adoption by Jordanian banks for outside consumption is a relatively new phenomenon. This new responsibili- ty carries with it requirements for a high-quality accounting system, and the possibility of increasing bank capitalisation. Published stock prices are one of the most influential financial report items and, as such, are known to have an effect on bank activities, management decisions, and investment decisions. Finally, the existence of strong IFRS adoption in a bank can lead to improvements in professional conduct in banking transactions and can help to restrict the chances of financial report mistakes.

\section{METHODS}

This study adopts Kim et al.'s (2014) framework in order to test this research hypotheses ( $H 1$ and $H 2$ ). It uses a sample of 9 out of 15 Jordanian banks for the period 2000-2016, with 6 banks excluded for several reasons: (1) 4 banks for missing data during the period of study, (2) and 2 banks that started their business after 2000. The Jordanian banking sector is recognized as being amongst the strongest of the country's financial services industry. In 2017, the Jordanian banking system showed an $18.82 \%$ growth of GDP, which is recognized as one of its largest economic sectors. The Jordanian banking sector began in 1948 when the Arab Bank moved its main office from Jerusalem to Amman. The Central Bank of Jordan (CBJ) is an independent bank that upholds the security of banks in Jordan. This research entire sample is classified under adopted IFRS, with adoptions both compulsory and voluntary ${ }^{1}$, which enables the researcher to explore more factors that could impact the relationship between IFRS compliance and stock price. The authors' extracted data related to IFRS compliance from the annual published financial reporting on the Amman Stock Exchange (ASE), and the data that related to stock price were collected using (1) Amman Stock Exchange (ASE) publications and (2) DataStream.

In this study, several techniques adapted from the prior literature were used to measure study variables. According to Masum (2014), stock prices measured by calculating stock return, which is addressed as the dependent variable. The independent variable is IFRS compliance;

1 IFRS adoption started in Jordanian banks in 2005; however, IAS was used before this time, which means that the period before 2005 is related to voluntary adoption. 
a dummy variable $(0,1)$ is used to measure it, where zero is given if the firms do not comply with IFRS and 1 is given if the firms do comply with IFRS (Nandi \& Soobaroyen, 2015). As in prior literature, several control variables were used to isolate the effects of IFRS compliance on firm performance, such as (1) firm size, (2) return on assets (ROA), (3) firm leverage, and (4) cash from operating activities. Each of these variables is measured as follows:

1) firm size was measured using the natural logarithm of total assets at the end of each year, and was expected to relate positively to stock prices;

2) ROA was measured by dividing net income over average total assets, and was expected to have a positive association with stock prices;

3) firm leverage was measured by dividing Tier 1 capital $^{2}$ by the bank's average total consolidated assets; and

4) cash from operating activities was measured by dividing cash flow from operating activities by total assets at the beginning of a year and was expected to relate positively to stock prices.

As discussed in prior literature, all control variables are expected to be significantly related to IFRS compliance (Abbadi et al., 2016; Alley, Adebayo, \& Oligbi, 2016; Mulyani et al., 2016).

The effect of IFRS compliance on stock prices in Jordanian banks is examined using panel data methodology. Several criteria related to panel data methodology added more accuracy to this research results, such as increased variability, heter- ogeneity, reduced multicollinearity among study variables, and increased data information and efficiency. However, to accomplish the main aim of this research - to examine the impact of IFRS compliance on stock prices in Jordanian banks formula below was established.

$$
\begin{aligned}
& \text { STOpi }=\alpha_{0}+\beta_{1} \text { IFRSco }+\beta_{2} \text { Fsize }+ \\
& +\beta_{3} \text { ROA }+\beta_{4} \text { Flev }+\beta_{5} \text { CFOA }+\varepsilon_{t},
\end{aligned}
$$

where STOpi is the stock return, IFRSco is the IFRS compliance, Fsize is the firm size, $R O A$ is return on assets, Flev is firm leverage, and $C F O A$ is cash from operating activities.

\section{RESULTS}

The research results, examining the effect of IFRS compliance on stock price for Jordanian banks, are presented in the following sections. The descriptive statistics analysis is presented, followed by the Pearson's correlation coefficient to show the nature of the relationship between IFRS compliance and explanatory and control variables. This research panel data used regression analysis to determine the impact and relationship of the dependent, independent, and control variables in Jordanian banks on the Amman Stock Market.

\subsection{Descriptive statistics and univariate analysis}

This section presents the descriptive statistics and univariate analysis results for this research variables, which measure the relationship between IFRS compliance and stock prices in Jordanian banks. In addition, the authors present descriptive measures for the control variables.

\begin{tabular}{|c|c|c|c|c|c|}
\hline \multicolumn{6}{|c|}{ Model sample } \\
\hline Variables & Median & Min & Max & Mean & Standard deviation \\
\hline$S P$ & -0.02 & -0.74 & 2.31 & 0.08 & 0.48 \\
\hline IFRS & 1 & 0.00 & 1.00 & 0.87 & 0.34 \\
\hline Fsize & 20.96 & 0.00 & 23.98 & 20.81 & 2.78 \\
\hline$R O A$ & 1.38 & -1.48 & 5.74 & 1.36 & 0.84 \\
\hline Flev & 86.9 & 0.00 & 82.61 & 13.91 & 8.27 \\
\hline CFAO & 0.03 & -0.31 & 0.22 & 0.03 & 0.07 \\
\hline
\end{tabular}

Table 1. Descriptive statistics and univariate test for explanatory variables

2 Tier 1 capital, used to describe the capital adequacy of a bank, is core capital that includes equity capital and disclosed reserves. Equity capital is inclusive of instruments that cannot be redeemed at the option of the holder. 
As shown in Table 1 , the mean values of stock return are 0.08 , which means that this result is consistent with prior literature, particularly in developing countries (Masum, 2014). Possibly, the low stock price averages in Jordanian banks could be attributed to factors like the 2008 financial crisis, the revolutions in the Middle East beginning in 2010, and oil price reductions since 2014. Furthermore, Table 1 shows the information of descriptive statistics of other variables impacting the stock prices of banks listed on the Amman Stock Market during the period of 2000 to 2016. IFRS compliance, which is the independent variable in the model, ranges from 0 to 1 with a mean value of 0.87 , and standard deviation is 0.34 . The first control variable is firm size, with a mean value of 20.81 and a standard deviation of 2.78 . Return on assets, which is the second control variable, ranges from -1.48 to 5.74 , and its mean value and standard deviation are 1.36 and 0.84 , respectively. Financial leverage ratio, which is the third control variable, has a minimum value 0 and maximum value 82.61, with value mean 13.91 and standard deviation of 8.27. Finally, the fourth control variable is cash from operating activities, with mean value of 0.03 and standard deviation of 0.07 .

\subsection{Variance Inflation Factor (VIF), tolerance (1/VIF) tests and heteroskedasticity test}

In this section, the authors discuss the results of VIF and tolerance results (Lin, 2008). Hair (1995) documented if variance inflation factor test is greater than 10 and tolerance test is less than 0.2 that means there is multicollinearity. Table 2 presents the no multicollinearity problem in this study model. All VIF values are less than 10 and tolerance values are more than 0.2. This, in turn, means that collinearity is not an issue in this study.

Table 2. VIF and tolerance results

\begin{tabular}{l|c|c}
\hline & \multicolumn{2}{c}{ Panel data 2000 to 2016 } \\
\hline Variable & VIF & Tolerance \\
\hline IFRSCO & 1.60 & 0.62 \\
\hline FSize & 1.25 & 0.80 \\
ROA & 1.22 & 0.82 \\
\hline FleV & 1.34 & 0.75 \\
\hline CFOA & 1.08 & 0.92 \\
\hline Mean VIF & 1.30 & - \\
\hline
\end{tabular}

Note: STOpi is the stock return; IFRSco is the IFRS compliance; Fsize is the firm size; ROA is return on assets; Flev is firm leverage, and $C F O A$ is cash from operating activities.
Heteroskedasticity means that the variances of random errors in ordinary least square regression (OLS) are inconstant (Seekell et al., 2012; Kaufman, 2013). Therefore, the heteroskedasticity problem possibility occurs when the magnitude of the residuals appears to be correlated to the independent variable value. This study used Breusch-Pagan/ Cook-Weisberg test to determine whether the data set of this research has been affected as a result of the heteroskedasticity problem. Table 3 shows that study model is not affected by heteroskedasticity since the chi2 value (1.33) is insignificant, which means that the authors have to accept the null hypothesis; this stated, 'All variances of random errors in OLS regression for study model are constant'. This, in turn, led the OLS regression in the proper method to test the relationship across the study variables. The existence of the multicollinearity and heteroscedasticity problems has led the researchers to seek to identify proper methods to test their hypotheses: for example, generalized Least Square Regression (GLS), which is considered an alternative way to solving multicollinearity and heteroskedasticity problems.

Table 3. Heteroskedasticity results

Breusch-Pagan / Cook-Weisberg test for
Ho: Constant variance
Variables: fitted values of $\boldsymbol{V}$

\subsection{Correlation analysis}

Prior literature has stated that a higher degree of association between variables may lead to a multicollinearity problem - predominantly when the correlation coefficients are more than \pm 0.8 (Abdul Rahman \& Haneem Mohamed Ali, 2006). Consequently, this multicollinearity problem may bias the results when using the regression model, and thus may influence the capability to use regression to identify the association between dependent and independent variables.

This analysis presents the correlation matrix for this research variables. Table 4 is presented in order to show the correlation between variables. The table shows that stock return is negatively asso- 
ciated with IFRS and firm size, significant at the 0.01 level, with IFRS compliance at the 0.1 level with firm size variables. ROA, financial leverage ratio and cash from operating activities are positively associated with stock return but are seen to be insignificant; these results are consistent with the results garnered in the work by Masum (2014), where the correlation coefficients for dividend yield and retention ratio are significant at levels of 0.1 . Finally, a negative relationship was established between cash from operating activities and financial leverage ratio.

Table 4 shows that, for the model sample, the variables that have a positive degree of correlation with IFRS are firm size and return on assets. On the other hand, firm leverage and cash from operating activities are negatively related to IFRS. These results support the results in Tables 2 and 3 , which show no existence of multicollinearity and heteroscedasticity problems (see Section 3.2).

Table 4. Pearson correlation coefficient between variables

\begin{tabular}{l|c:c:c:c:c:c}
\hline Variables & SP & IFRS & Fsize & ROA & Flev & CFOA \\
\hline$S P$ & 1.000 & - & - & - & - & - \\
IFRS & $-0.380^{* * *}$ & 1.000 & - & - & - & - \\
Fsize & $-0.149^{*}$ & $0.289^{*}$ & 1.000 & - & - & - \\
ROA & 0.030 & $0.396^{* *}$ & $0.163^{*}$ & 1.000 & - & - \\
Flev & 0.044 & -0.090 & $0.146^{*}$ & 0.029 & 1.000 & - \\
CFOA & 0.084 & -0.136 & 0.074 & 0.056 & $0.167^{*}$ & 1.000 \\
\hline
\end{tabular}

Notes: ${ }^{*}$ Correlation is significant at the 0.01 level (2-tailed). * Correlation is significant at the 0.05 level (2-tailed).

\subsection{Augmented Dickey-Fuller test (ADF)}

This test has been applied in order to clarify that this research variables (dataset) are clear from non-stationary problem. The ADF test stated that the variable follows a unit-root process; the null hypothesis is that the variable contains a unit root (non-stationary). On the other hand, the alternative hypothesis shows that stationary process as generating the variable (the variable is stationary). Accordingly, the existence of the unit root led to biased results through the use of the OLS regression model (Diebold \& Kolian, 2000; Perron \& Qu, 2007), where: if probability = zero, the variable is stable for the period of time, and can, therefore, use any method of least squares, such as OLS. If probability $<0$, this means that the researchers cannot use the least method because it leads to biased results (Johansen, 1995). Table 5 presents the results of the ADF test.

As shown in Table 5, all the variables in this current study are stationary and stable, since the $p$-value is 0.00 for all variables (SP, IFRS, firm size, ROA, leverage ratio, and cash from operating activities). This means that there is $0 \%$ chance that this research model has unit root, which is equivalent to saying, 'there is $0 \%$ chance that its process is non-stationary'. Therefore, the authors can reject the null hypothesis and conclude that the process is stationary. Accordingly, the use of ordinary least squares (OLS) is suitable for our dataset.

\section{EMPIRICAL RESULTS}

Hypotheses 1 and 2 were tested by examining the relationship between IFRS compliance and stock return in Jordanian banks, using the evidence and theoretical framework discussed above. A multi-regression model was used, as discussed in section 2, to show the nature of the effect of each control variable on IFRS compliance, as the independent variable.

Table 6 indicates that the T statistic for the model is high and significant at $\mathrm{p}<0.000$, suggesting that all data are statistically valid. The $R^{2}$ values are high for the model sample at $19 \%$, and adjust-

Table 5. ADF unit root results

\begin{tabular}{l|c|c|c|c|c|c}
\hline \multicolumn{1}{c}{ Variables } & $\boldsymbol{P}$-value & T-statistic & $\mathbf{1 \%}$ Critical value & $\mathbf{5 \%}$ Critical value & $\mathbf{1 0 \%}$ Critical value & Result \\
\hline$S P$ & 0.00 & -13.59 & -3.50 & -2.89 & -2.58 & Stable \\
\hline IFRS & 0.00 & -4.48 & -3.50 & -2.89 & -2.58 & Stable \\
\hline Fsize & 0.00 & -11.259 & -3.50 & -2.89 & -2.58 & Stable \\
$R O A$ & 0.00 & -9.228 & -3.50 & -2.89 & -2.58 & Stable \\
Flev & 0.00 & -12.52 & -3.50 & -2.89 & -2.58 & Stable \\
CFOA & 0.00 & -11.18 & -3.50 & -2.89 &...- \\
\hline
\end{tabular}


ed $R^{2}$ is also high with $16 \%$. In comparison with the prior studies (e.g., Sletten, 2012), the authors found that their $R^{2}$ values ranged is closed to this research, which means that the model in this research has better explanatory power.

Table 6 summarizes hypotheses 1 and 2 in the detailed empirical setting. IFRS compliance is highly negatively related to stock return, where the main hypothesis stated that higher IFRS compliance would relate to higher stock return. Therefore, the research first hypothesis is not supported with presented results, which are, however, inconsistent with prior studies that found a positive relationship between both variables (Abbadi et al., 2016; Alley, Adebayo, \& Oligbi, 2016). This result may be related to contemporary political and economic circumstances, such as the 2008 financial crisis, the revolutions in the Middle East beginning in 2010, and oil and gold price reductions. These factors directly affect the Jordanian financial situation, because large contracts have been broken and many investors have withdrawn their investments from these banks.

Hypothesis 2, which stated that the effect of IFRS compliance on stock return differs between firms with higher and lower levels of IFRS compliance, is supported; a positive relationship exists between IFRS compliance and stock return for certain sizes of Jordanian banks. This result is consistent with prior studies, such as Kim et al. (2014) and Li (2010). Furthermore, the findings in Table 3 show that cash flow from operating activities and firm leverage negatively affected the relationship between stock price and IFRS compliance in Jordanian banks, which is also not consistent with prior literature that finds both of them positively influence the IFRS compliance and other variables (Kim et al., 2014; Mulyani et al., 2016). These results might refer to numerous issues, the financial crisis of 2008, cultural factors, and economic and political climate in Middle East. The Global Financial Crisis is an issue that presently influences business performance; consequently, prior literature pays attention to reviewing the impact of the financial crisis, especially with regards IFRS adoption and stock price. On this issue, Jiang et al. (2017) have stated that the findings in prior studies have a different effect on stock price. They have proposed that the financial crisis could lead to further decreases in stock price in line with (1) reducing business earnings by reducing their pricing, and (2) reducing their earnings in order to minimise investors interesting to increase their investments. In this regard, Singh et al. (2017) documented that cultural factors, such as religion, language and Hofstede's cultural dimensions, have a different relationship with stock market from one region to another.

Li (2010) stated that leverage ratio and cash from operating activities have significant positive relationship with stock return at the level of 0.05 . Finally, leverage ratio has positive relationship with stock return with insignificant relationship with stock return in Jordanian banks. On the other hand, firm size has insignificant negative relationship with stock return in Jordanian banks. These results are partially inconsistent with prior studies, (e.g., Mulyani et al., 2016), who found serious impacts of their control variables on the dependent variables.

Table 6. Regression results for the study model

\begin{tabular}{|c|c|c|c|c|}
\hline STOpi (N, 144) & $\begin{array}{c}\text { Exp } \\
\text { signe }\end{array}$ & Coef. & $t$ & $P>t$ \\
\hline IFRSCO & + & -0.43 & -4.32 & $* * *$ \\
\hline Fsize & + & -0.02 & -1.12 & - \\
\hline ROA & + & 0.12 & 2.60 & $* *$ \\
\hline Flev & + & 0.44 & 2.86 & $* *$ \\
\hline CFOA & + & 0.06 & 0.12 & - \\
\hline \multirow{2}{*}{$\begin{array}{l}\text { Adj } R^{2} \\
\text { Adj } R^{2} \text { Adj }\end{array}$} & $19 \%$ & - & - & - \\
\hline & $16 \%$ & - & - & - \\
\hline$T$ statistics & $6.68^{* * *}$ & - & - & - \\
\hline Prob. $\mathrm{t}$ & 0.000 & - & - & - \\
\hline
\end{tabular}

Notes: STOpi is the stock return; IFRSco is the IFRS compliance; Fsize is the firm size; ROA is return on assets; Flev is firm leverage, and CFOA is cash from operating activities. ${ }^{* * *},{ }^{* *}$ and ${ }^{*}$ indicate significant at the $0.001,0.05$ and 0.10 levels, respectively.

\section{CONCLUSIONS}

IFRS is deemed one of the most important standards to improve the financial statement quality for the adopters and enhance the quality of bank sectors. Those improvements are predictable to be capable to give substantial assistances to banking market in Jordan, which in turn, allows more banks that are still 
not listed on the Amman Stock Market to be possessed into stock returns. Existing studies with similar goal have supported the empirical evidence that the adoption of IFRS increases the opportunities of investors to invest in banks and firms in order to increase the countries' markets, which makes the stock return base always solid. Therefore, the research hypothesis that relates to the differences in the firms level is supported particularly for firms that their managers expose news (related to IFRS compliance) about firm assessment, which favourably affects stock return and withholds news unfavourably impacting stock return.

The study concludes that IFRS compliance negatively affects stock return and the ROA has a positive relationship with stock return in Jordanian banks. This has positive impact on decision makers, especially investors and senior managers in Jordanian banks as well as legislators and regulators in Jordan. Therefore, it also helps to determine the nature of the relationship between IFRS compliance and stock return.

This study used and applied a new empirical evidence in the context of Jordanian banks, which added new contribution to the relevant literature. Furthermore, this study is a one of the few focusing on the relationship between IFRS compliance and stock returns in the Middle Eastern countries after the financial crisis of 2008 and the recent political issues. The second hypothesis in this study was supported with a positive relationship, while the first hypothesis revealed results quite opposite to research expectations, which may be attributed to the several factors mentioned in the discussion section. The impacts of IFRS compliance on stock return do differ between firms with higher IFRS compliance and firms with lower compliance, but stock return is actually lower for firms with higher levels of IFRS compliance.

This study presented several contributions, where this research is one of the first studies that examined the relationship between IFRS compliance and stock return in Middle East, particularly in Jordanian banks, in order to provide in-depth information to understand the nature of the dynamics of the association between these two issues. This in turn allows a richer study to carry out underlying the processes and mechanism by which IFRS compliance and stock return in Jordanian banks are assessed. To the authors' knowledge, this study is the first to have used a categorical technique for association between IFRS compliance and stock return in banking sector, since most prior studies have been conducted on the industrial sector as a result of competitive and technical pressures in this sector.

Several issues could make the relationship between IFRS adoption and stock returns different from one country to the next, such as cultural factors, financial crisis, religion and language. Cultural factors are categorised under different perceptions, which makes it difficult to determine these factors. Nevertheless, ignoring cultural factors could lead businesses to further problems that could affect their performance (Sivakumar \& Sathyanarayanan, 2007). Finally, the study has significant implications for those activities in which change dynamics in IFRS compliance can appear, diffuse and be applied on stock return influences. This provides a new contextual framework for studying these issues based on a concentrated and holistic view of an explanatory quantitative research.

\section{REFERENCES}

1. Abbadi, S., Hijazi, Q., \& Al-

Rahahleh, A. (2016). Corporate

Governance Quality and Earnings

Management: Evidence from

Jordan. Australasian Accounting.

Business and Finance Journal, 10,

54-75. https://doi.org/10.14453/

aabfi.v10i2.4
2. Abdul Rahman, R., \& Haneem Mohamed Ali, F. (2006). Board, audit committee, culture and earnings management: Malaysian evidence. Managerial Auditing Journal, 21, 783-804. https://doi. org/10.1108/02686900610680549
3. Alali, F. A., \& Foote, P. S. (2012). The Value Relevance of International Financial Reporting Standards: Empirical Evidence in an Emerging Market. The International Journal of Accounting, 47, 85-108. https://doi. org/10.1016/j.intacc.2011.12.005 
4. Ali, A., Akbar, S., Ormrod, P., \& Shah, S. Z. A. (2016). The Impact and Implications of International Financial Reporting Standards in the United Kingdom: Evidence from the Alternative Investment Market. Australian Accounting Review, 26, 360-375. https://doi. org/10.1111/auar.12140

5. Alley, Adebayo, \& Oligbi (2016). Corporate Governance and Financial Performance Nexus: Any Bidirectional Causality? International Journal of Management and Economics, 50, 82-99.

6. Anderson, M., Okafor, O. N., \& Warsame, H. (2016). IFRS and value relevance: evidence based on Canadian adoption. International Journal of Managerial Finance, 12, 136-160. https://doi.org/10.1108/ IJMF-02-2015-0033

7. Ansary, O. A. E. E., \& El-Azab, M. H. (2017). The Impact of Stock Dividends and Stock Splits on Shares' Prices: Evidence from Egypt. Accounting and Finance Research, 6(4), 96-114. https://doi. org/10.5430/afr.v6n4p96

8. Ball, R. (2006). International Financial Reporting Standards (IFRS): pros and cons for investors. Accounting and Business Research, 36, 5-27. https://doi.org/10.1080/0 0014788.2006.9730040

9. Barth, M. E., Landsman, W., \& Lang, M. H. (2008). International Accounting Standards and Accounting Quality. Journal of Accounting Research, 46(3), 467-498. https://doi.org/10.1111/ j.1475-679X.2008.00287.x

10. Byun, \& Rozeff (2003). Long-run Performance after Stock Splits: 1927 to 1996. The Journal of Finance, 58(3), 1063-1085. https:// doi.org/10.1111/1540-6261.00558

11. Capkun, V., Collins, D., \& Jeanjean, T. (2016). The effect of IAS/IFRS adoption on earnings management (smoothing): A closer look at competing explanations. Journal of Accounting and Public Policy, 35, 352-394. https://doi.org/10.1016/j. jaccpubpol.2016.04.002

12. Christensen, H. B., Hail, L., \& Leuz, C. (2013). Mandatory
IFRS reporting and changes in enforcement. Journal of Accounting and Economics, Conference Issue on Accounting Research on Classic and Contemporary, 56, 147-177. https://doi.org/10.1016/j.jacceco.2013.10.007

13. Chua, W. F., \& Taylor, S. L. (2008). The rise and rise of IFRS: An examination of IFRS diffusion. Journal of Accounting and Public Policy, International Financial Reporting Standards, 27, 462-473. https://doi.org/10.1016/j.jaccpubpol.2008.09.004

14. Diebold, F. X., \& Kilian, L. (2000). Unit-root tests are useful for selecting forecasting models. Journal of Business and Economic Statistics, 18, 265-273. https://doi.org/10.1016/S01692070(00)00095-9

15. Dye, R. A. (1985). Disclosure of Nonproprietary Information. Journal of Accounting Research, 23, 123-145. https://doi. org/10.2307/2490910

16. Elbannan, M. A. (2011). Accounting and stock market effects of international accounting standards adoption in an emerging economy. Review of Quantitative Finance and Accounting, 36(2), 207-245. https://doi.org/10.1007/ s11156-010-0176-1

17. Foster, G. (1973). Stock Market Reaction to Estimates of Earnings per Share by Company Officials. Journal of Accounting Research, 11, 25-37. https://doi. org/10.2307/2490279

18. Hair, J. F. (1995). Multivariate Data Analysis: With Readings. Prentice Hall.

19. Hodgdon, C., Tondkar, R. H., Adhikari, A., \& Harless, D. W. (2009). Compliance with International Financial Reporting Standards and auditor choice: New evidence on the importance of the statutory audit. The International Journal of Accounting, 44, 33-55. https://doi.org/10.1016/j.intacc.2008.12.003

20. Jiang, Y., Yu, M., \& Hashmi, S. M (2017). The Financial Crisis and Co-Movement of Global Stock
Markets - A Case of Six Major Economies. Sustainability, 9, 1-18.

21. Johansen, S. (1995). Likelihoodbased Inference in Cointegrated Vector Autoregressive Models. Oxford University Press.

22. Kaufman, R. L. (2013). Heteroskedasticity in Regression: Detection and Correction. SAGE Publications.

23. Kim, J.-B., Shi, H., \& Zhou, J. (2014). International Financial Reporting Standards, institutional infrastructures, and implied cost of equity capital around the world. Review of Quantitative Finance and Accounting, 42(3), 469-507. https://doi.org/10.1007/s11156013-0350-3

24. Kothari, Shu, \& Wysocki (2009). Do Managers Withhold Bad News? Journal of Accounting Research 47, 241-276.

25. Li, S. (2010). Does Mandatory Adoption of International Financial Reporting Standards in the European Union Reduce the Cost of Equity Capital? The Accounting Review, 85, 607-636.

26. Lin, F.-J. (2008). Solving Multicollinearity in the Process of Fitting Regression Model Using the Nested Estimate Procedure. Qual Quant, 42, 417-426. https:// doi.org/10.1007/s11135-0069055-1

27. Loureiro, G. R., \& Taboada, A. G. (2011). Do Improvements in the Information Environment Affect Real Investment Decisions? SSRN Electronic Journal. https://doi. org/10.2139/ssrn.1952593

28. Maggina, A., \& Black, E. L. (2016). The impact of IFRS on financial statement data in Greece. Journal of Accounting in Emerging Economies, 6(1), 69-90. https://doi. org/10.1108/JAEE-02-2013-0013

29. Masum, A. (2014). Dividend Policy and Its Impact on Stock Price - A Study on Commercial Banks Listed in Dhaka Stock Exchange (SSRN Scholarly Paper No. ID 2724964). Social Science Research Network, Rochester, NY.

30. Mazzi, F., André, P., Dionysiou, D., \& Tsalavoutas, I. (2017). 
Compliance with goodwillrelated mandatory disclosure requirements and the cost of equity capital. Accounting and Business Research, 47, 268-312. https://doi.or g/10.1080/00014788.2016.1254593

31. Mulyani, E., Singh, H., \& Mishra, S. (2016). Dividends, leverage, and family ownership in the emerging Indonesian market. Journal of International Financial Markets, Institutions and Money, 43, 16-29. https://doi.org/10.1016/j. intfin.2016.03.004

32. Nnadi, M., \& Soobaroyen, T. (2015). International financial reporting standards and foreign direct investment: The case of Africa. Advances in Accounting, 31, 228-238. https://doi.org/10.1016/j. adiac.2015.09.007

33. Perron, P., \& Qu, Z. (2007). A simple modification to improve the finite sample properties of $\mathrm{Ng}$ and Perron's unit root tests. Economics Letters, 94, 12-19. https://doi. org/10.1016/j.econlet.2006.06.009

34. Rezaei, F. (2012). Efficient or opportunistic earnings management with regards to the role of firm size and corporate governance practices.
Interdisciplinary Journal of Contemporary Research in Business, 3(9), 1312-1322. Retrieved from http://www.journal-archieves14. webs.com/1312-1322.pdf

35. Rudra, T., \& Bhattacharjee, D. (2012). Does IFRs Influence Earnings Management? Evidence from India. Journal of Management Research, 4, 1-13.

36. Seekell, D. A., Carpenter, S. R. Cline, T. J., \& Pace, M. L. (2012) Conditional Heteroskedasticity Forecasts Regime Shift in a Whole-Ecosystem Experiment. Ecosystems, 15, 741-747. https://doi. org/10.1007/s10021-012-9542-2

37. Singh, V., Li, B., \& Roca, E. (2017). How pervasive is the effect of culture on stock market linkages? Evidence across regions and economic cycles. Applied Economics, 49, 4209-4230. https:// doi.org/10.1080/00036846.2017.1 279268

38. Sivakumar, N., \& Sathyanarayanan (2007). Impact of Indian Cultural Variables on Stock Market Activity and Movement - the 'Rahu - Umbra Region of the Cosmos - Kala' Hypothesis. Journal of Financial Management \& Analysis, 20, 36.
39. Skinner, D. J. (1997). Earnings disclosures and stockholder lawsuits. Journal of Accounting and Economics, 23, 249-282. https://doi.org/10.1016/S01654101(97)00010-4

40. Sletten, E. (2012). The effect of stock price on discretionary disclosure. Review of Accounting Studies, 17(1), 96-133. https://doi. org/10.1007/s11142-011-9165-4

41. Tucker, J. W., \& Zarowin, P. (2006). Timeliness of Firms' Voluntary Disclosure of Good and Bad News (Working Paper).

42. Turki, H., Wali, S., \& Boujelbene, Y. (2017). IFRS Mandatory Adoption Effect on the Information Asymmetry: Immediate or Delayed? Australasian Accounting, Business and Finance Journal, 11, 55-77. https://doi.org/10.14453/aabfj. v11i1.5

43. Yurt, C., \& Ergun, U. (2015). The IFRS Adoption and Accounting Quality: A Comprehensive Trend Analysis. International Journal of Academic Research in Economics and Management Sciences, 4, 1119. https://doi.org/10.6007/IJAREMS/v4-i2/1631 